\title{
Risk and protective factors for chronic diseases in adults: a population-based study
}

\author{
Fatores de risco e de proteção para doenças crônicas em adultos: \\ um estudo de base populacional
}

Danielle Cristina Guimarães da Silva ${ }^{1}$

Wellington Segheto ${ }^{2}$

France Araújo Coelho ${ }^{3}$

Vanessa Guimarães Reis ${ }^{3}$

Sílvia Helena Oliveira Morais ${ }^{3}$

Milene Cristine Pessoa ${ }^{4}$

Giana Zarbato Longo ${ }^{3}$

${ }^{1}$ Centro das Ciências

Biológicas e da Saúde,

Universidade Federal do

Oeste da Bahia. R. Professor

José Seabra de Lemos lado

par, Recanto dos Pássaros.

47808-021 Barreiras BA

Brasil.

daniellenut@hotmail.com

${ }^{2}$ Faculdade Governador

Ozanam Coelho. Ubá MG

Brasil.

${ }^{3}$ Departamento de Nutrição

e Saúde, Universidade

Federal de Viçosa. Viçosa

MG Brasil.

${ }^{4}$ Escola de Enfermagem,

Universidade Federal

de Minas Gerais. Belo

Horizonte MG Brasil.
Abstract The article describes the relative frequency ok of risk and protective behaviors for chronic non-communicable diseases (NCDs) in adults residing in Viçosa, Brazil. A cross-sectional population-based study including 1,226 adults living in the municipality. We used a structured questionnaire containing questions sociodemographic and behavioral The risk and protection factors evaluated were: smoking, physical activity, excessive consumption of alcohol and food consumption. The proportion of risk and protection factors was calculated in the total population, according to gender, education and socioeconomic status. The studied population has a high frequency of risk factors for NCDs, such as excessive consumption of alcoholic beverages, habit of consuming whole milk, habit of eating meat with visible fat, regular consumption of soft drinks and $78.5 \%$ did not achieve the minimum recommendation for physical activity in leisure time. With regard to protective factors, $86.2 \%$ of the population reported regular consumption of fruits and vegetables, and $73 \%$, of beans. It was found the highest frequency of risk factors in among males, in younger people and middle socioeconomic status. This population has an urgent need for public policy of municipal planning to change this current scenario.

Key words Risk factors, Chronic disease, Health surveys
Resumo Este artigo descreve a frequência relativa de comportamentos de risco e de proteção para doenças crônicas não transmissiviveis (DCNT) em adultos de Viçosa, Brasil. Foi realizado um estudo transversal de base populacional, incluindo 1226 adultos residentes do município. Utilizou-se um questionário estruturado, contendo questões sociodemográficas e comportamentais. Os fatores de risco/proteção avaliados foram: tabagismo, prática de atividade física, consumo abusivo de bebida alcóolica e consumo alimentar. A proporção dos fatores de risco/proteção foi calculada na população total, de acordo com sexo, escolaridade e nível socioeconômico. A população avaliada apresenta elevada frequência de fatores de risco para DCNT, como consumo abusivo de bebidas alcoólicas, hábito de consumir leite integral, ingerir carnes com gorduras visiveis, consumo regular de refrigerantes e 78,5\% não atingiram a recomendação mínima para atividade física no lazer. Em relação aos fatores de proteção, $86,2 \%$ da população relataram consumir regularmente frutas e vegetais, e $73 \%$, feijões. Verificou-se a maior frequência de fatores de riscos no sexo masculino, em indivíduos de menor idade e nível socioeconômico intermediário. Nesta população há urgência nas políticas públicas de planejamento municipal para mudar o atual cenário.

Palavras-chave Fatores de risco, Doenças crônicas, Inquéritos epidemiológicos 


\section{Introduction}

Concern about the influence of modern eating habits, physical inactivity and tobacco and alcohol use in the development of chronic non-communicable diseases (NCD) has increased in many countries. Epidemiological studies have confirmed the association between these major risk factors and the rise of $\mathrm{NCDs}^{1-4}$. Importantly, these diseases have been the leading causes of death in both developed and developing countries $^{5,6}$.

In the last two decades, the dietary pattern of the Brazilian population has been changing with the predominance of high saturated-fat, high-sugar and low-fiber foods. The Consumer Expenditure Survey (2008-2009) published alarming data on the excessive consumption of sugar and saturated fat, which was reported by $61 \%$ and $82 \%$ participants of the survey, respectively, and low fiber intake reported by $68 \%$ of the participants ${ }^{7}$. Besides these mentioned aspects, national estimates reveal that physical inactivity and alcohol and tobacco use have a high prevalence in the country ${ }^{8-10}$.

To modify this scenario, the World Health Organization launched the Global Strategy on Diet, Physical Activity and Health to promote health through public health actions and preventive measures ${ }^{11}$. In Brazil, the Ministry of Health launched the Strategic Action Plan for the Fight of Chronic Non-communicable Diseases, 20112022, aiming at promoting the development and implementation of integrated public policies and evidence-based prevention and control of NCDs and their risk factors ${ }^{12}$. The recent update and publication of the Dietary Guidelines for the Brazilian Population, in 2014, complements the strategies to face the current health scenario ${ }^{13}$.

The identification of factors associated with the risk or protection for the development of NCDs in a population is a requirement in order to assist in the planning of actions to improve public health ${ }^{14}$, since the modifiable risk factors such as smoking, physical inactivity, unhealthy diet and the harmful use of alcohol are possible to be minimized by seeking healthy behaviors ${ }^{8,15}$.

Therefore, the objective of this study was to describe the frequency of risk and protective behaviors for the development of NCDs in adults between 20 and 59 years of age, living in the urban area of the municipality of Viçosa, Minas Gerais, Brazil.

\section{Materials and methods}

This is a descriptive epidemiological, cross-sectional study conducted by the study group on health and nutrition of Viçosa (ESA/Viçosa), using a population-based household survey in the urban area of Viçosa - Minas Gerais. The population of the city according to the census of 2010 was 72.220 habitants, $93 \%$ in the urban area. Related to gender, there is a predominance of women, constituting $51.5 \%$ of the population. Regarding the age distribution, children correspond to $6.05 \%$ of the population, teenagers $16.18 \%$, adults $60.13 \%$, and $17.34 \%$ are elderly people. About the ethnic composition they are: white, Asian, Indians, black and brown, spread over $46.60 \%, 0.82 \%, 00.12 \%, 15.50 \%$ and $36.96 \%$, respectively. The municipal human development index (MHDI) is 0.775 , placing it in 11th place among all cities in the state and has an average per capita income of $\mathrm{R} \$ 521.67^{16}$. Viçosa has unique characteristics compared to other cities with the same size because of the large number of college students residing in it. The study population consisted of adults aged between 20 and 59 years of age at the time of the survey, men and women living in the urban area of the municipality.

Data were collected between September 2012 and March 2014, involving a team of interviewers and supervisors previously trained to apply the questionnaire.

The sample size was calculated by the formula for prevalence estimates, considering the total number of individuals aged between 20 and 59 years living in the urban area of Viçosa, amounting to 43,431 people $^{16}$. Prevalence was estimated at $50 \%$, as a result of this study be part of a larger project consisting of other outcomes and associated factors, $95 \%$ confidence level, the sampling error of 4.1 percent and deff (design effect) 1.55. There was a $20 \%$ increase in losses and refusals. Calculations using the software Epi-Info 3.5.2 $2^{\otimes 17}$ showed a minimum sample size (n) of 1049 participants. Exclusion criteria included: pregnant women, postpartum women, individuals that were bedridden or unable to take measurements, individuals with cognitive/intellectual difficulty or found it difficult to respond to the questionnaire.

The Brazilian Institute of Geography and Statistics (IBGE) divides the city into 99 census sectors, among which 30 sectors were randomly selected to be included in the study. Within each sector, a new random draw was carried out to set 
a starting point from which to choose the homes to be visited and include all eligible participants from each household.

A structured, standardized questionnaire was used to collect sociodemographic, and behavioral data. This study evaluates the frequency of risk and protective factors in adults living in Viçosa. Among the risk factors, the following variables were evaluated: smoking, physical inactivity, alcohol abuse, habitual consumption of whole milk and fat meats (red meat with visible fat and / or chicken with skin) and regular consumption of soft drink. Protective factors evaluated were: sufficient physical activity during leisure time (leisure) and regular consumption of beans, fruits and vegetables.

The sociodemographic variables were: age in completed years and categorized into ten-year periods (20-29, 30-39, 40-49 and 50-59 years), schooling in completed years of study and set to 0-3 4-7 and $\geq 8$ years of study and socioeconomic status, according to the Brazilian Association of Research Companies ${ }^{18}$ and classified into socioeconomic levels A and B, C and D and E. Behavioral variables included smoking data, physical activity level and abuse of alcohol.

The smoking data were categorized in two groups: smokers and ex-smokers; and non-smokers $^{19}$. The physical activity level (PAL) was assessed using the International Physical Activity Questionnaire (IPAQ), long version, validated for the Brazilian population ${ }^{20}$. This instrument is divided into four domains (physical activity at work; physical activity as a means of transportation; physical activity at home and physical activity for recreation, sport, exercise and leisure). In this study only the fourth domain (physical activity recreation, sport, exercise and leisure) was used to identify the PAL, which was calculated by adding the time spent on moderate physical activities more twice the time with vigorous activities. We used the cutoff point 150 minutes / week ("reach the recommendation" $\geq 150 \mathrm{~min}$ utes / week; "does not reach the recommendation" $<150$ minutes / week) ${ }^{21}$. The abuse of alcohol was considered present if there was ingestion of more than five drinks on a single occasion in the last thirty days for men, and more than four drinks for women. The standard dose set on half a bottle or a can of beer, a glass of wine or a shot of spirits ${ }^{22}$.

The characteristics related to the eating habits of the participants were based on a structured questionnaire consisting of direct questions relating to food consumption, proposed by the
Risk and Protective Factors Surveillance System for Chronic Diseases by Telephone Interviews (VIGITEL) $^{23}$. Thus, the consumption of fruits, vegetables, beans and soft drinks was considered regular when respondents reported consumption of these foods more than five times a week. The habit of consuming whole milk and meat with visible fat (red meat with visible fat and / or chicken with skin) was also investigated.

Quality control was conducted by the random application of questions in the questionnaire in $10 \%$ of the sample through telephone contact and double entry of the questionnaire by previously trained typists. After checking the data consistency, analyses were performed using the statistical software STATA 13.1, taking into account the sample design effect using the svy tab commands. Sample weights considering the variables sex, age and education were calculated to equalize differences in socio-demographic composition of the sample in relation to the composition of the adult population of the city, according to the census distribution of $2010^{16}$. The proportions and respective intervals with 95\% confidence level were calculated for the risk and protective factors for chronic diseases of the overall sample and stratified according to the variables: gender, age and socioeconomic status. The statistical significance was verified with the ${ }^{2}$ test, considering $\mathrm{p}<0.05$.

The project was approved by the Ethics Committee of the Federal University of Viçosa, protocol number 008/12. Free consent signatures were requested and the survey participants were informed previously to data collection.

\section{Results}

The response rate was $95.64 \%$, getting the full 1226 eligible adults that were interviewed. With respect to sociodemographic characteristics, the sample was predominantly composed of women, corresponding to $50.8 \%$. Most of the subjects were in the age group 20-29 years, with 8 or more years of schooling and middle socioeconomic status (class C) (Table 1).

Regarding behavioral characteristics, $65.4 \%$ were non-smokers, $39.3 \%$ reported abusive alcohol consumption and $78.5 \%$ did not achieve the minimum recommendation for physical activity during leisure. As for eating habits, 59.0\% of respondents reported regular consumption of whole milk, 55.4\% commonly consumed meats with excess fat and $27.8 \%$ of the individuals men- 
Table 1. Demographic, socioeconomic, behavioral and food consumption characteristics of the population, Viçosa, MG, 2012-2014.

\begin{tabular}{|c|c|c|}
\hline Variable & $\begin{array}{l}\text { Relative Frequency } \\
(\%)\end{array}$ & $\begin{array}{c}\text { Confidence interval } \\
(95 \% \mathrm{CI})\end{array}$ \\
\hline \multicolumn{3}{|l|}{ Sex } \\
\hline Male & 49.2 & $(45.7-52.7)$ \\
\hline Female & 50.8 & $(47.3-54.3)$ \\
\hline \multicolumn{3}{|l|}{ Age (years) } \\
\hline $20-29$ & 32.8 & $(24.3-42.5)$ \\
\hline $30-39$ & 25.3 & $(21.1-29.9)$ \\
\hline $40-49$ & 22.9 & $(18.3-28.3)$ \\
\hline $50-59$ & 19.0 & $(15.1-23.7)$ \\
\hline \multicolumn{3}{|l|}{ Education (years) } \\
\hline $0-3$ & 12.3 & $(7.3-19.7)$ \\
\hline $4-7$ & 16.0 & $(11.8-21.4)$ \\
\hline$>=8$ & 71.7 & $(61.1-80.3)$ \\
\hline \multicolumn{3}{|l|}{ Socioeconomic level (ABEP) } \\
\hline High (A and B) & 24.5 & $(19.0-31.1)$ \\
\hline Middle (C) & 64.7 & $(59.9-69.2)$ \\
\hline Low (D and $\mathrm{E})$ & 10.8 & $(7.3-15.6)$ \\
\hline \multicolumn{3}{|l|}{ Smoking } \\
\hline Non-smoker & 65.4 & $(59.9-70.6)$ \\
\hline Smoker and ex-smoker & 34.6 & $(29.3-40.1)$ \\
\hline \multicolumn{3}{|l|}{ Physical activity at leisure } \\
\hline Do not reach the recommendation & 78.5 & $(71.3-84.3)$ \\
\hline Reach the recommendation & 21.5 & $(15.7-28.6)$ \\
\hline Abusive consumption of alcohol ${ }^{\mathrm{a}}$ & 39.3 & $(35.4-43.4)$ \\
\hline Habit of consuming whole milk & 59.0 & $(54.7-63.1)$ \\
\hline Habit of consuming meat without removal of visible fat & 55.4 & $(50.3-60.3)$ \\
\hline Regular consumption of soft drinks ${ }^{\mathrm{b}}$ & 27.8 & $(23.8-32.3)$ \\
\hline Regular consumption of beans ${ }^{c}$ & 86.2 & $(83.2-88.8)$ \\
\hline Regular consumption of fruits and vegetables ${ }^{\mathrm{d}}$ & 73.0 & $(67.3-77.9)$ \\
\hline
\end{tabular}

tioned the regular consumption of soft drinks. The consumption of bean for five or more days a week was reported by $86.25 \%$ of the sample and of fruits and vegetables by $73 \%$.

Tables 2, 3 and 4 show the proportions and the respective intervals with $95 \%$ confidence for the risk and protection factors for NCDs in this population, according to sex, age and socioeconomic status. Among the behavioral and socio demographic factors studied, smoking and ex-smoking were more common in males, slightly higher in individuals aged between 20 and 29, with differences between ages and higher in individuals of socioeconomic class $\mathrm{C}$. The difficulty in reaching the minimum recommendation of physical activity was predominant in females and more frequently in individuals aged between 20 and 29 and socioeconomic class C, with statistical differences detected between socioeconomic levels.

Abusive consumption of alcohol was more frequently related to male participants (54.4\%), with differences between the sexes, predominant in individuals aged between 20 and 29, with differences between age and socioeconomic class C.

In relation to characteristics of food consumption, men showed more behaviors considered risk factors than women, with more frequent habitual consumption of whole milk, 51.7\%, meat with visible fat, $58.2 \%$, with significant differences between sexes $(\mathrm{p}<0.001)$ and consumption of soft drinks for five or more days a week, 
Table 2. Distribution of risk and protective factors for chronic diseases in the population, according to sex, Viçosa, MG, 2012-2014.

\begin{tabular}{|c|c|c|c|}
\hline \multirow{2}{*}{ Risk and protection factors } & \multicolumn{2}{|c|}{ Relative frequency ${ }^{\star}(95 \% \mathrm{CI})$} & \multirow[t]{2}{*}{ p-value ex $^{* *}$} \\
\hline & Men & Women & \\
\hline Smoking & & & 0.09 \\
\hline Non-smoker & $45.9(41.9-50.0)$ & $54.1(50.0-58.1)$ & \\
\hline Smoker and ex-smoker & $55.4(46.0-64.4)$ & $44.5(35.5-53.9)$ & \\
\hline Physical activity at leisure & & & 0.07 \\
\hline Do not reach the recommendation & $46.1(41.7-50.5)$ & $53.9(49.5-58.3)$ & \\
\hline Reach the recommendation & $66.7(59.8-72.9)$ & $33.3(27.0-40.2)$ & \\
\hline Abusive consumption of alcohol ${ }^{\mathrm{a}}$ & $54.4(48.9-60.1)$ & $24.6(21.6-28.0)$ & 0.00 \\
\hline Habit of consuming whole milk & $51.7(46.6-56.8)$ & $48.3(43.2-53.4)$ & 0.13 \\
\hline $\begin{array}{l}\text { Habit of consuming meat without removal } \\
\text { of visible fat }\end{array}$ & $58.2(52.6-63.5)$ & $41.8(36.5-47.4)$ & 0.00 \\
\hline Regular consumption of soft drinks ${ }^{\mathrm{b}}$ & $56.2(50.8-61.4)$ & $43.8(38.6-49.1)$ & 0.00 \\
\hline Regular consumption of beans $s^{\mathrm{c}}$ & $50.4(46.5-54.2)$ & $49.6(45.7-53.5)$ & 0.04 \\
\hline Regular consumption of fruits and vegetables ${ }^{\mathrm{d}}$ & $47.3(42.4-52.2)$ & $52.7(47.8-57.5)$ & 0.07 \\
\hline
\end{tabular}

Table 3. Distribution of risk and protective factors for chronic diseases in the population, by age group, Viçosa, MG, $2012-2014$.

\begin{tabular}{|c|c|c|c|c|c|}
\hline \multirow{3}{*}{ Risk and protection factors } & \multicolumn{4}{|c|}{ Relative frequency ${ }^{\star}(95 \% \mathrm{CI})$} & \multirow[t]{2}{*}{ p-value ${ }^{\star *}$} \\
\hline & \multicolumn{4}{|c|}{ Age } & \\
\hline & $(20-29$ years $)$ & $(30-39$ years $)$ & $(40-49$ years $)$ & $(50-59$ years $)$ & \\
\hline Smoking & & & & & 0.00 \\
\hline Non-smoker & $38.4(29.4-48.2)$ & $27.6(21.8-34.1)$ & 20.1(15.8 - 25.1) & $13.9(\mathbf{1 0 . 2}-\mathbf{1 8 . 6})$ & \\
\hline Smoker and ex-smoker & $22.1(14.5-32.3)$ & $20.8(16.0-26.5)$ & $28.2(21.4-36.2)$ & $28.7(22.2-36.2)$ & \\
\hline Physical activity at leisure & & & & & 0.00 \\
\hline $\begin{array}{l}\text { Do not reach the } \\
\text { recommendation }\end{array}$ & $26.1(18.1-36.0)$ & $25.2(20.2-31.0)$ & $25.4(19.4-32.4)$ & $23.3(18.5-28.8)$ & \\
\hline Reach the recommendation & $46.8(37.0-56.9)$ & $26.2(20.4-32.8)$ & $13.9(8.6-21.5)$ & $13.1(7.2-22.3)$ & \\
\hline Abusive consumption of alcohol ${ }^{\mathrm{a}}$ & $41.0(\mathbf{2 9 . 6}-\mathbf{5 3 . 3})$ & $29.4(21.9-38.0)$ & $17.7(10.9-27.5)$ & $11.9(6.9-19.6)$ & 0.00 \\
\hline Habit of consuming whole milk & $34.9(25.9-44.9)$ & $26.2(21.6-31.2)$ & $22.0(16.3-29.1)$ & $16.9(12.9-21.6)$ & 0.16 \\
\hline $\begin{array}{l}\text { Habit of consuming meat without } \\
\text { removal of visible fat }\end{array}$ & $31.6(22.2-42.9)$ & $28.2(22.9-34.1)$ & $23.5(17.5-30.6)$ & $16.7(11.9-22.7)$ & 0.18 \\
\hline $\begin{array}{l}\text { Regular consumption of soft } \\
\text { drinks }^{\text {b }}\end{array}$ & $47.2(36.6-58.1)$ & $27.2(19.3-37.0)$ & $18.5(12.5-26.3)$ & $7.1(4.6-10.4)$ & 0.00 \\
\hline Regular consumption of beans ${ }^{c}$ & $32.2(23.8-41.9)$ & $26.0(21.6-30.9)$ & $22.7(17.6-28.7)$ & $19.1(14.8-24.0)$ & 0.62 \\
\hline $\begin{array}{l}\text { Regular consumption of fruits and } \\
\text { vegetables }^{\text {d }}\end{array}$ & $34.5(26.1-43.9)$ & $24.2(20.3-28.6)$ & $21.9(17.2-27.5)$ & $19.4(15.3-24.1)$ & 0.27 \\
\hline
\end{tabular}

$56.2 \%$, with significant differences between sexes $(\mathrm{p}<0.001)$. The regular consumption of beans was higher for males, with significant differences between the sexes. All consumption variables were observed with higher frequency in individ- 
Table 4 Distribution of risk and protective factors for chronic diseases in the population, according to the socioeconomic level, Viçosa, MG, 2012-2014.

\begin{tabular}{|c|c|c|c|c|}
\hline \multirow[b]{2}{*}{ Risk and protection factors } & \multicolumn{3}{|c|}{ Relative frequency ${ }^{\star}(95 \% \mathrm{CI})$} & \multirow[t]{2}{*}{ p-value ${ }^{\star *}$} \\
\hline & $\begin{array}{l}\text { High socioeconomic } \\
\text { status (A and B) }\end{array}$ & $\begin{array}{c}\text { Middle socioeconomic } \\
\text { status (C) }\end{array}$ & $\begin{array}{l}\text { Low socioeconomic } \\
\text { status (D and E) }\end{array}$ & \\
\hline Smoking & & & & 0.63 \\
\hline Non-smoker & $25.5(19.8-32.0)$ & $64.7(59.1-70.0)$ & $9.8(6.2-15.1)$ & \\
\hline Smoker and ex-smoker & $22.8(15.8-31.6)$ & $64.6(56.2-72.1)$ & $12.5(6.0-24.4)$ & \\
\hline Physical activity at leisure & & & & 0.00 \\
\hline $\begin{array}{l}\text { Do not reach the } \\
\text { recommendation }\end{array}$ & $19.7(14.4-25.7)$ & $66.6(61.8-71.0)$ & $13.7(9.2-20.5)$ & \\
\hline Reach the recommendation & $34.7(27.6-42.5)$ & $61.1(\mathbf{5 2 . 0}-\mathbf{6 9 . 4})$ & $4.2(2.1-8.2)$ & \\
\hline Abusive consumption of alcohol ${ }^{\mathrm{a}}$ & $27.6(20.8-35.5)$ & $64.4(56.1-72.0)$ & $7.9(4.4-14.0)$ & 0.16 \\
\hline Habit of consuming whole milk & $23.1(17.8-29.4)$ & $67.3(62.3-72.0)$ & $9.5(5.8-15.1)$ & 0.15 \\
\hline $\begin{array}{l}\text { Habit of consuming meat } \\
\text { without removal of visible fat }\end{array}$ & $23.5(17.8-30.4)$ & $69.0(62.7-74.7)$ & $7.5(3.6-14.8)$ & 0.06 \\
\hline $\begin{array}{l}\text { Regular consumption of soft } \\
\text { drinks }{ }^{b}\end{array}$ & $24.2(17.4-32.5)$ & $68.1(60.8-74.6)$ & $7.7(4.0-14.5)$ & 0.37 \\
\hline Regular consumption of beans ${ }^{c}$ & $24.1(18.5-30.8)$ & $64.4(59.2-69.2)$ & $11.5(7.6-17.0)$ & 0.24 \\
\hline $\begin{array}{l}\text { Regular consumption of fruits } \\
\text { and vegetables }{ }^{\mathrm{d}}\end{array}$ & $29.5(23.4-36.4)$ & $61.5(56.4-66.5)$ & $9.0(5.7-13.9)$ & 0.00 \\
\hline
\end{tabular}

\section{Discussion}

Chronic non-communicable diseases have an important role in the current health profile of the population. In Brazil, there is an increase in the prevalence of these diseases, causing many complaints. There are important national and international population studies on the relationship between demographic, socioeconomic and behavioral aspects and the rates of risk factors for $\mathrm{NCDs}^{24-26}$. However, though there are population-based studies that aim to determine the prevalence of risk and protective factors for NCDs in small cities ${ }^{27}$, they are scarce. In addition, as previously mentioned, this survey was conducted in a university town and may have peculiar results due to the profile of the population.

The descriptive analysis of the participants' lifestyles in this study shows that this population has a high risk of developing NCDs because of the high prevalence of abusive consumption of alcohol, habit of consuming whole milk and eating meat with visible fat, regular consumption of soft drinks and predominant physical inactivity. Such behaviors are typical of college students, especially those who live without living parents, as in our sample.
The nationwide telephone surveys carried out in Brazil have shown a tendency to reduction in the use of cigarettes ${ }^{10,23,28}$. The prevalence of smoking in this study was described as inferior to some population-based surveys ${ }^{9,29}$, however, higher than the most recent data published by VIGITEL $^{10}$. In addition, the highest frequency of smoking was demonstrated in men, in younger individuals and in the middle socioeconomic class. These findings point out the importance of evaluating the effectiveness of awareness campaigns and regulatory and restrictive measures adopted in the municipality, since the tobacco constitutes the most important risk factor for NCDs ${ }^{29}$.

Although the Global Strategy on Diet, Physical Activity and Health ${ }^{11}$ recommends that individuals engage in adequate levels of physical activity throughout their lives, in Brazil, the frequency of physical activity during leisure shown by VIGITEL data in $2013^{10}$ is only $33.8 \%$. This may result in increased risk of overweight and cardiovascular diseases in a population ${ }^{4}$. Similar to reports of other Brazilian studies ${ }^{3,30,31}$, we found high rates of physical inactivity and that men are more active than women, hence, the latter group should receive greater attention, to 
fight inactivity. The low frequency of physically active individuals is also in agreement with the findings of Rombaldi et al. ${ }^{32}$.

Alcohol consumption has been demonstrated across diverse populations $s^{33}$, and the frequency of Brazilians that report abusive alcohol consumption is $16.4 \%{ }^{10}$. Cibeira et al. ${ }^{34}$ found association between alcohol consumption and sociodemographic factors in a sample of women from Porto Alegre, RS. The authors reported that $30 \%$ of the group stated to consume alcoholic beverages on a regular basis, and the better-educated and higher income were associated with consumption of higher amounts of alcohol.

In this study, we investigated the reported alcohol consumption in the last 30 days, from this point, we found that $39.3 \%$ of adults residents in Viçosa, who were interviewed in the survey, reported abusive alcohol consumption, showing that the expectations and goals for reducing alcohol prevalence outlined in the Action Plan of the Ministry of Health ${ }^{12}$ have not been achieved in the municipality. One possible explanation for this scenario is the demographic profile of the city's population, which is made up of a high number of young university students. Another important result was the highest alcohol consumption among men. VIGITEL ${ }^{10}$ reported in its latest publication that alcohol abuse is greater in younger individuals (18-34 years), corroborating our findings. Heavy alcohol consumption was investigated by Alexandre et al. ${ }^{1}$; Moura et al. ${ }^{3}$; Laranjeira et al. ${ }^{33}$ and, similarly, men reported greater consumption than women.

In a study to identify sociodemographic and behavioral factors related to adult eating habits in the city of Goiania, GO, Alexandre et al. ${ }^{1}$, showed that regular consumption of whole milk was similar for both sexes, corroborating what was detected in this study. Data of the last VIGITEL reports ${ }^{10,23}$ indicated higher frequencies of whole milk consumption in the male population. It is noteworthy that these frequencies are considered high in view of the benefits obtained with healthier food choices such as skim milk ${ }^{35}$, as the habitual consumption of animal products such as whole milk is considered an important risk factor for the development of cardiovascular diseases and certain types of cancer ${ }^{36}$. This study also found more frequent consumption of whole milk in the younger group, who also reported middle economic level.

Rombaldi et al. ${ }^{32}$ presented data from a population-based study conducted in the city of Pelotas, RS, where $32.7 \%$ of the assessed adults reported regular consumption of fatty meats. International population-based studies also reported the habitual fat consumption of $33.7 \% \%^{37}$ and between 34 and $36 \%{ }^{38}$. We found higher percentages than those reported, however, they were consistent, when evaluating the distribution of fat consumption by gender, since men usually consume more fatty foods than women ${ }^{39}$. The proportion in the usual intake of meat with visible fat was higher in individuals of the middle economic class.

In relation to soft drink consumption, it has been found that the frequency of consumption investigated in this study was similar to that found by Longo et al. ${ }^{9}$ in a population-based study in Lages, SC. In addition, the increased consumption of soft drinks reported by young men is consistent with studies that had the same focus ${ }^{9,10,32}$. We also found that the individuals belonging to socioeconomic level C reported the highest consumption of these products. According to data of the Household Budget Survey (POF 2002-2003), there was a $400 \%$ increase in the soft drink participation in household food purchases by Brazilians, which is higher in lower income classes ${ }^{40}$. Brazilian studies have shown that this scenario is repeated with college students ${ }^{41,42}$.

Information collected by the World Health Survey ${ }^{43}$ shows that the frequency of daily consumption of fruits and vegetables among the Brazilian adult population is around $41 \%$ and $30 \%$, respectively, with a higher consumption found in the higher socioeconomic groups. According to data from the Household Budget Survey and VIGITEL ${ }^{7,23}$ low consumption of fruits and vegetables have become a recurring phenomenon in Brazil and in Latin-American countries ${ }^{44}$.

Several epidemiological studies have shown that consumption of fruits and vegetables may be associated with lower incidence and mortality related to chronic non-communicable diseas$\mathrm{es}^{45,46}$. In this study, the prevalence in the regular consumption of beans, fruits and vegetables were higher than the findings published by VIGITEL ${ }^{10}$, however, there was consistency regarding the higher frequency of consumption of these foods among women than men. Similarly, Alexandre et al. ${ }^{1}$ showed that women tend to consume more often foods that are considered protective. It is worth noting that this study found the highest frequency of regular consumption of fruits and vegetables and beans among individuals of lower age, unlike the reports by the World Health Survey ${ }^{43}$ In Brazil, the latest research that investigated the regular bean consumption, found that 
the prevalence of consumption is higher among young adults and low educational levels ${ }^{10}$.

A baseline study conducted in Anchieta, Brazil, to determine the prevalence of risk and protective factors for NCDs through a household survey detected a high prevalence in the consumption of meat with visible fat, low prevalence of physical activity during leisure time and consumption of five servings of fruits and vegetables on five or more days of the week ${ }^{27}$. These results show that the observed risk factors indicate similar favorable conditions for the rise of NCDs in the group investigated by this study, requiring an intervention by the municipality to modify these factors which are preventable. A comparison with the study of Sousa et al. ${ }^{42}$ on students from the State University of Santa Cruz, BA, shows similar scenarios between the populations, which is characterized by inadequate consumption of fruits and vegetables, lower levels of physical activity at leisure and excessive alcohol consumption and smoking.

The implementation of small cities in universities promotes the economic, cultural and urban education development, the part of the population, however, can modify the different determinants of risk and protection for chronic diseases. Therefore, the adoption of integrated and sustainable actions to reduce the prevalence of risk factors associated with chronic diseases is critical to the development of effective strategies to promote the health of the population.
As a limiting factor of this study, there is the possible occurrence of recall bias on respondents' answers relating to months prior to the application of the questionnaire, which can underestimate the prevalence of some factors evaluated, as the prevalence of abusive consumption of alcohol. It is noteworthy that the use of eating markers recommended by the VIGITEL may appear different when comparing with the publication of the Food Guide for the Brazilian population, which recommended the preferential consumption of food raw or minimally processed as healthy consumption markers. However, consumer indicators discussed in this work have satisfactory validity and reliability, tested in previous studies ${ }^{47,48}$, showing they can be used.

\section{Conclusion}

The prevalence of consumption of fruits, vegetables and beans was high, however, there was a prevalence of risk factors for the development of chronic diseases, including high prevalence of abusive consumption of alcohol, habit of consuming whole milk and eating meat with visible fat, regular consumption of soft drinks and physical inactivity. It is of utmost importance to disseminate these findings to health professionals and the general public, aiming at better planning of programs for the prevention and reduction of such diseases in this municipality.

\section{Collaborations}

DCG Silva, W Segheto, FA Coelho, VG Reis, SHO Morais contributed to the data collection and analyses of this study, wrote the initial draft of the manuscript and assembled the final version. MC Pessoa contributed to study design and data analyses. GZ Longo was the supervisor of this study, contributed to study design, developed analyses and data analyses. 


\section{References}

1. Alexandre VP, Peixoto MRG, Schmitz BAS, Moura EC. Fatores associados às práticas alimentares da população adulta de Goiânia, Goiás, Brasil. Rev bras epidemiol 2014; 17(1):267-280.

2. Jaime PC, Figueiredo ICR, Moura EC, Malta DC. Fatores associados ao consumo de frutas e hortaliças no Brasil, 2006. Rev Saude Publica 2009; 43(Supl. 2):57-64.

3. Moura EC, Silva SA, Malta DC, Morais Neto OL. Fatores de risco e proteção para doenças crônicas: vigilância por meio de inquérito telefônico, VIGITEL, Brasil, 2007. Cad Saude Publica 2011; 27(3):486-496.

4. World Health Organization (WHO). Diet, nutrition and prevention of chronic diseases. Report of a Joint WHO/FAO Expert Consultation. Geneva: WHO; 2003. (WHO Technical Report Series 916).

5. Oliveira-Campos M, Rodrigues-Neto JF, Silveira MF, Neves DMR, Vilhena JM, Oliveira JF, Magalhães JC, Drumond D. Impacto dos fatores de risco para doenças crônicas não transmissíveis na qualidade de vida. Cien Saude Colet 2013; 18(3):873-882.

6. Malta DC, Morais Neto OL, Silva JB. Plano de ações estratégicas para enfrentamento das doenças crônicas não transmissíveis (DCNT) no Brasil: 2011-2022. Epidemiol Serv Saude 2011; 20(4):425-438.

7. Instituto Brasileiro de Geografia e Estatística (IBGE). Pesquisa de orçamentos familiares 2008-2009: Análise do consumo alimentar pessoal no Brasil. Rio de Janeiro: IBGE; 2011.

8. Brunori EHFR, Cavalcante AMRZ, Lopes CT, Lopes JL, Barros ALBL. Tabagismo, consumo de álcool e atividade física: associações na síndrome coronariana aguda. Acta Paul Enferm 2014; 27(2):165-172.

9. Longo GZ, Neves J, Castro TG, Pedroso MRO, Matos IB. Prevalência e distribuição dos fatores de risco para doenças crônicas não transmissíveis entre adultos da cidade de Lages (SC), sul do Brasil, 2007. Rev bras epidemiol 2011; 14(4):698-708.

10. Brasil. Ministério da Saúde (MS). Secretaria de Vigilância em Saúde. Vigitel Brasil 2014: Vigilância de fatores de risco e proteção para doenças crônicas por inquérito telefônico. Brasília: MS; 2015.

11. World Health Organization (WHO). Global strategy on diet, physical activity and health. Geneva: WHO; 2004. (Fifty-Seventh World Health Assembly WHA 57.17).

12. Brasil. Ministério da Saúde (MS). Secretaria de Vigilância em Saúde. Departamento de Análise de Situação de Saúde. Plano de Ações Estratégicas para o Enfrentamento das Doenças Crônicas Não Transmissíveis (DCNT) no Brasil 2011-2022. Brasília: MS; 2011.

13. Brasil. Ministério da saúde (MS). Secretaria de atenção à saúde. Departamento de Atenção Básica. Guia alimentar para a população brasileira. $2^{\text {a }}$ ed. Brasília: MS; 2014.

14. Lopes ACS, Caiaffa WT, Sichieri R, Mingoti SA, LimaCosta MF. Consumo de nutrientes em adultos e idosos em estudo de base populacional: projeto Bambuí. Cad Saude Publica 2005; 21(4):1201-1209.

15. Marrero SL, Bloom DE, Adashi EY. Noncommunicable diseases. A global health crisis in a new world order. $J$ Am Med Assoc 2012; 307(19):2037-2038.

16. Instituto Brasileiro de Geografia e Estatística (IBGE). Censo Demográfico 2010. Características da população e dos domicílios. Rio de Janeiro: IBGE; 2010.
17. Dean AG, Dean JA, Colombier D, Brendel KA, Smith DC, Burton AH, Dicker RC, Sullivan K, Fagan RF, Arner TG. Epi Info, version 6: a word processing, database, and statistics program for epidemiology on microcomputers. Atlanta: Centers for Disease Control and Prevention; 1994.

18. Associação Brasileira de Empresas de Pesquisa (ABEP). Critério de classificação econômica Brasil. [Internet]. [acessado 2013 Dez 10].Disponível em: http://www. abep.org/codigosguias/CCEB2012.

19. Menezes AMB, Victora CG, Perez-Padilla R. The Platino project: methodology of a multicenter prevalence survey of chronic obstructive pulmonary disease in major latinamerican cities. BMC Med Res Methodol 2004; 4(15):1-17.

20. Pardini R, Matsudo SM, Araújo T, Matsudo V, Andrade E, Braggion G, Andrade D, Oliveira L, Figueira Jr A, Raso V. Validação do questionário internacional de nível de atividade física (IPAQ - versão 6): estudo piloto em adultos jovens brasileiros. Rev Bras Ciên e Mov 2001; 9(3):45-51.

21. Haskell WL, Lee IM, Pate RR, Powell KE, Blair SN, Franklin BA, Macera CA, Heath GW, Thompson PD, Bauman A. Physical Activity and Public Health: Updated Recommendation for Adults from the American College of Sports Medicine and the American Heart Association. Med Sci Sport Exer 2007; 39(8):1423-1434.

22. Furlan-Viebig R, Pastor-Valero M. Desenvolvimento de um questionário de frequência alimentar para o estudo de dieta e doenças não transmissíveis. Rev Saude Publica 2004; 38(4):581-584.

23. Brasil. Ministério da Saúde (MS). Secretaria de Vigilância em Saúde. Vigitel Brasil 2012: Vigitel Brasil 2011: Vigilância de fatores de risco e proteção para doenças crônicas por inquérito telefônico. Brasília: MS; 2012.

24. Instituto Nacional de Câncer (INCA). Inquérito domiciliar sobre comportamentos de risco e morbidade referida de doenças e agravos não transmissíveis: Brasil, 15 capitais e Distrito Federal, 2002-2003. Rio de Janeiro: INCA; 2004.

25. Borges MC, Santos LP, Zago AM, Silva BG, Silva SG, Mola CL. Socioeconomic development of cities and risk factors for non-communicable diseases: a comparative study across Brazilian state capitals. J Public Health 2016; 38(4):653-359.

26. Moodie R, Stuckler D, Monteiro C, Sheron N, Neal B, Thamarangsi T, Lincoln P, Casswell S. Profits and pandemics: prevention of harmful effects of tobacco, alcohol, and ultra-processed food and drink industries. Lancet 2013; 381(9867):670-679.

27. Yokota RTC, Iser BPM, Andrade RLM, Santos J, Meiners MMMA, Assis DM, Bernal RTI, Malta DC, Moura L. Vigilância de fatores de risco e proteção para doenças e agravos não transmissíveis em município de pequeno porte, Brasil, 2010. Epidemiol Serv Saude 2012; 21(1):55-68.

28. Brasil. Ministério da Saúde (MS). Secretaria de Vigilância em Saúde. Vigitel Brasil 2007: Vigilância de fatores de risco e proteção para doenças crônicas por inquérito telefônico. Brasília: MS; 2009. 
29. Malta DC, Iser BPM, Sá NNB, Yokota RTC, Moura L, Claro RM, Luz MGC, Bernal RIT. Tendências temporais no consumo de tabaco nas capitais brasileiras, segundo dados do VIGITEL, 2006 a 2011. Cad Saude Publica 2013; 29(4):812-822.

30. Mielke GI, Hallal PC, Rodrigues GBA, Szwarcwald CL, Santos FV, Malta DC. Prática de atividade física e hábito de assistir à televisão entre adultos no Brasil: Pesquisa Nacional de Saúde 2013. Epidemiol Serv Saude 2015; 24(2):277-286

31. Hallal PC, Dumith SC, Bastos JP, Reichert FF, Siqueira FV, Azevedo MR. Evolução da pesquisa epidemiológica em atividade física no Brasil: revisão sistemática. Rev Saude Publica 2007; 41(3):453-460.

32. Rombaldi AJ, Silva MC, Neutzling MB, Azevedo MR, Hallal PC. Fatores associados ao consumo de dietas ricas em gordura em adultos de uma cidade no sul do Brasil. Cien Saude Colet 2014; 19(5):1513-1521.

33. Laranjeira R, Pinsky I, Zaleski M, Caetano R. I Levantamento Nacional sobre os padrões de consumo de álcool na população brasileira. Brasília: Secretaria Nacional Antidrogas; 2007.

34. Cibeira GH, Muller C, Lazzaretti R, Nader GA, Caleffi M. Consumo de bebida alcoólica, fatores socioeconômicos e excesso de peso: um estudo transversal no sul do Brasil. Cien Saude Colet 2013; 18(12):3577-3584.

35. Brasil. Ministério da Saúde (MS). Guia alimentar para a população brasileira: promovendo a alimentação saudável. Brasília: MS; 2006.

36. García-Arenzana N, Navarrete-Muñoz EM, Lope V, Moreo P, Vidal C, Laso-Pablos S., Ascunce N, Casanova-Gómez F, Sánchez-Contador C, Santamariña C, Aragonés N, Gómez BP, Vioque J, Pollán M. Calorie intake, olive oil consumption and mammographic density among Spanish women. Int J Cancer 2014; 134(8):1916-1925.

37. Austin GL, Ogden LG, Hill JO. Trends in carbohydrate, fat, and protein intakes and association with energy intake in normal-weight, overweight, and obese individuals: 1971-2006. Am J Clin Nutr 2011; 93(4):836-843.

38. Pot GK, Prynne CJ, Roberts C, Olson A, Nicholson SK, Whitton C, Teucher B, Bates B, Henderson H, Pigott S, Swan G, Stephen AM. National diet and nutrition survey: fat and fatty acid intake from the first year of the rolling programme and comparison with previous surveys. Br J Nutr 2011; 107(3):405-415.

39. Monteiro CA, Moura EC, Jaime PC, Claro RM. Validade de indicadores do consumo de alimentos e bebidas obtidos por inquérito telefônico. Rev Saude Publica 2008; 42(4):582-589.
40. Levy-Costa RB, Sichieri R, Pontes NS, Monteiro CA Disponibilidade domiciliar de alimentos no Brasil: distribuição e evolução (1974-2003). Rev Saude Publica 2005; 39(4):530-540.

41. Marcondelli P, Costa THM, Schmitz BAS. Nível de atividade física e hábitos alimentares de universitários do $3^{\circ}$ ao $5^{\circ}$ semestres da área da saúde. Rev Nutr 2008 . 21(1):39-47.

42. Sousa TF, José HM, Barbosa AR. Condutas negativas à saúde em estudantes universitários brasileiros. Cien Saude Colet 2013; 18(12):3563-3575.

43. Jaime PC, Monteiro CA. Fruit and vegetable in take by Brazilian adults, 2003. Cad Saude Publica 2005: 21(Supl. 1):S19-S24.

44. Finucane MM, Stevens GA, Cowan MJ, Danaei G, Lin JK, Paciorek CJ, Singh GM, Gutierrez HR, Lu Y, Bahalim AN, Farzadfar F, Riley LM, Ezzati M; Global Burden of Metabolic Risk Factors of Chronic Diseases Collaborating Group (Body Mass Index). National, regional, and global trends in body-mass index since 1980: systematic analysis of health examination surveys and epidemiological studies with 960 country-years and 9.1 million participants. Lancet 2011; 377(9765):557-567.

45. Bazzano LA. The high cost of not consuming fruits and vegetables. J Am Diet Assoc 2006; 106(9):1364-1368.

46. Genkinger JM, Platz EA, Hoffman SC, Comstock GW, Helzlsouer KJ. Fruit, vegetable, and antioxidant intake and all-cause, cancer, and cardiovascular disease mortality in a community-dwelling population in Washington County, Maryland. Am J Epidemiol 2004; 160(12):1223-1233.

47. Mendes LL, Campos SF, Malta DC, Bernal RTI, Sá NNBD, Velásquez-Meléndez G. Validade e reprodutibilidade de marcadores do consumo de alimentos e bebidas de um inquérito telefônico realizado na cidade de Belo Horizonte (MG), Brasil. Rev Bras Epidemiol 2011; 14(Supl. 1):80-89.

48. Monteiro CA, Moura EC, Jaime PC, Claro RM. Validade de indicadores do consumo de alimentos e bebidas obtidos por inquérito telefônico. Rev Saude Publica 2008; 42(4):582-589.

Artigo apresentado em 13/12/2015

Aprovado em 03/04/2016

Versão final apresentada em 05/04/2016 